\title{
sciendo
}

CIVIL AND ENVIRONMENTAL ENGINEERING REPORTS

E-ISSN 2450-8594

CEER 2021; 31 (2): 0255-0273

DOI: $10.2478 /$ ceer-2021-0028

Original Research Article

\section{THE EVOLUTION OF NATURAL GAS PRICES IN EU COUNTRIES AND THEIR IMPACT ON THE COUNTRY'S MACROECONOMIC INDICATORS}

\author{
Erika LIPTÁKOVÁ ${ }^{1 *}$, Miroslav RIMÁR ${ }^{2}$, Ján KIZEK ${ }^{2}$, Zuzana ŠEFČÍKOVÁ ${ }^{1}$ \\ ${ }^{1}$ Department of Applied Mathematics and Business Informatics, Faculty of Economics \\ of the Technical University of Košice, Košice, Slovak Republic \\ ${ }^{2}$ Department of Process Technique, Faculty of Manufacturing Technologies of the \\ Technical University of Košice with a seat in Prešov, Prešov, Slovak Republic
}

\begin{abstract}
In the article, the authors characterize the current European market with natural gas, describing differences in prices for households and prices for companies from the point of view of individual components, where they focus more on taxes, levies and fees. The article further deals with the possible impact of the price of natural gas on the country's economy, more specifically, the correlation with inflation, unemployment and interest rates. The main aim of the authors is to establish an appropriate econometric model, which describes the impact of the price of natural gas together with the unemployment rate and interest rates on the inflation of the country. The price of natural gas, of this strategic raw material, is one of the factors that can influence the processes for low-carbon technologies or more precisely, the process of EU decarbonisation and with it the associated amount of $\mathrm{CO}_{2}$ emissions.
\end{abstract}

Keywords: natural gas, gas prices components, correlation, econometric model, HICP (Harmonised Index of Consumer Prices)

\footnotetext{
* Corresponding author: Department of Applied Mathematics and Business Informatics, Faculty of Economics of the Technical University of Košice, Nemcovej 32,040 01 Košice, Slovak Republic, e-mail: erika.liptakova@tuke.sk
} 


\section{INTRODUCTION}

Europe has long been dependent on imports of natural gas from outside Europe, and this dependence is increasing. In the 1970s, the EU's energy dependency was only $10 \%$, nowadays it is up to $50 \%$. This trend is mainly due to declining production of natural gas in Europe and, on the other hand, to increasing consumption. Due to the increased consumption of households and its increased use in industry, gas consumption also increased. Today, Europe is working to improve air cleanliness by replacing coal-fired power stations with gas-fired power plants [1].

The EU's current climate and energy policy is guided by the commitments and objectives agreed by the Brussels European Council in 2009, with a view to moving towards an energy-efficient, low-carbon economy by 2050 [2].

Fig. 1 shows a globally growing trend in natural gas consumption as part of the increasing energy consumption overall in the energy mix.

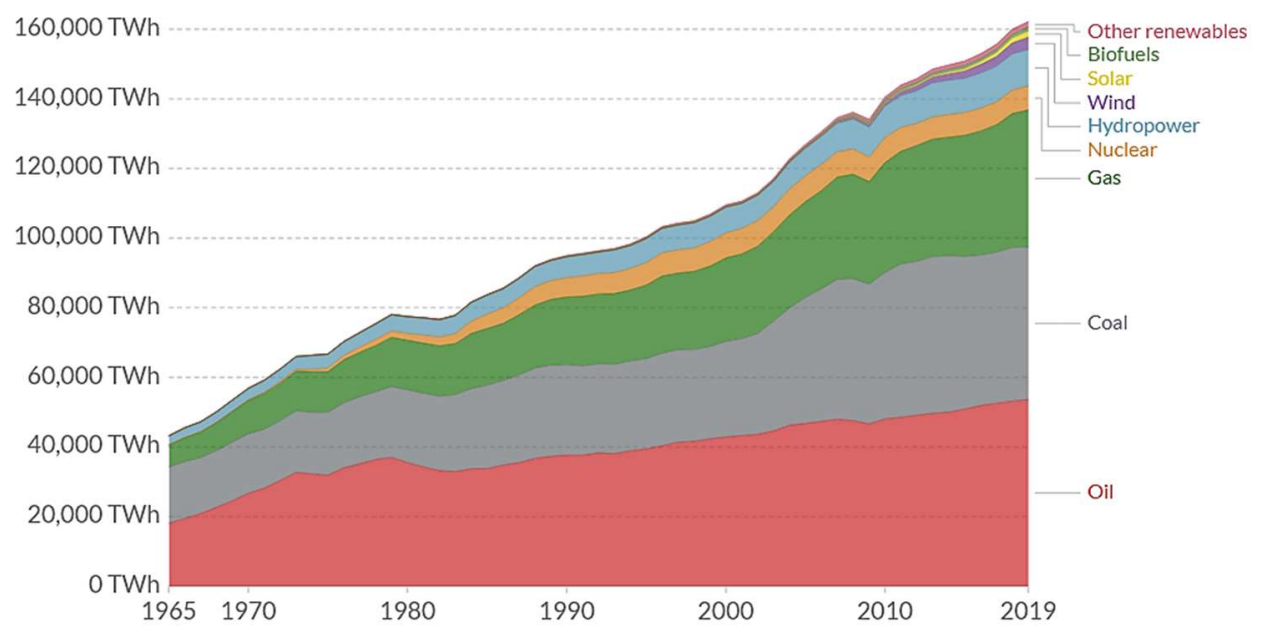

Fig.1. Energy consumption by source, World

Source: https://ourworldindata.org/energy-mix

Energy challenges which EU faces include, for example, increasing dependence on imports, lack of diversification, high and fluctuating energy prices, rising global energy demand, security risks affecting producing and transit countries, growing threats due to climate change, decarbonisation, slow progress in energy efficiency, challenges linked to an increasing share of renewable energy sources and the need for greater transparency, further integration and mutual interconnection of energy markets [3]. 
In 2018, the world consumed 3848.9 bcm (billion cubic meters) of natural gas, which represented a $23 \%$ share of the energy mix. In the case of natural gas, stocks are not a problem. Natural gas supplies $23 \%$ of the energy used worldwide and accounts for almost a quarter of electricity production. Natural gas is an all-round fuel and the growth in its consumption is linked to lower environmental loads compared to other fossil fuels, whether in terms of air quality or greenhouse gas emissions. According to Tomáš Malatinský President of the Slovak Gas and Diesel Association, natural gas will play an important role in the transition to lowemission energy. The natural gas market is also becoming more globalised thanks to the availability of shale gas and the increasing supply of liquefied natural gas (LNG), [4,5]. The predictions for the coming years show an increase in natural gas consumption, as the result of rising living standards in emerging countries and also the transition to cleaner forms of electricity [2].

The growth in natural gas consumption also raises issues of security, supply and storage of natural gas in underground gas storage facilities. In addition to LNG, the storage and transport of natural gas in the form of hydrates appears to be an alternative in this matter [6]. This factor may also contribute to influence of the price of natural gas.

\section{THE CURRENT EUROPEAN GAS MARKET}

The European Union is one of the largest natural gas importers in the world. At present, domestic production satisfies less than $30 \%$ of the European Union's natural gas needs. The EU has been for a long time dependent on imports of natural gas from other countries outside Europe. This addiction is constantly increasing.

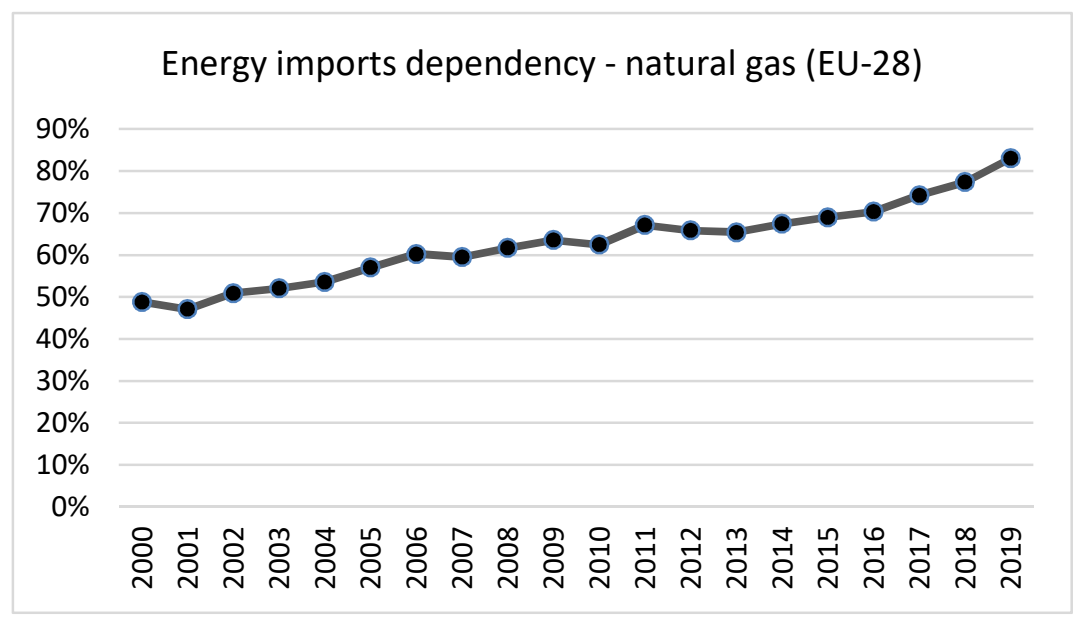

Fig.2. Dependency of EU-28 countries of natural gas import [7] 
In the 1970s of the last century, Europe's self-sufficiency reached the $90 \%$ border line. In 2000, the EU's self-sufficiency was $50 \%$, while in 2019 it was only $17 \%$. Fig.2 shows the growing trend of the EU's dependence on natural gas imports. In 2019 , up to $83 \%$ of natural gas had to be imported into Europe. A further decrease in self-sufficiency and thus a further increase in imports are anticipated for the future. The decreasing self-sufficiency is due to increasing consumption and declining natural gas production in Europe [1]

The main source of natural gas imports to the EU is Russia, which covered $39 \%$ of imports outside the EU in 2019. The second largest supplier of natural gas to EU countries is Norway (33\%), followed by Algeria (11\%) and other countries (Fig.3).

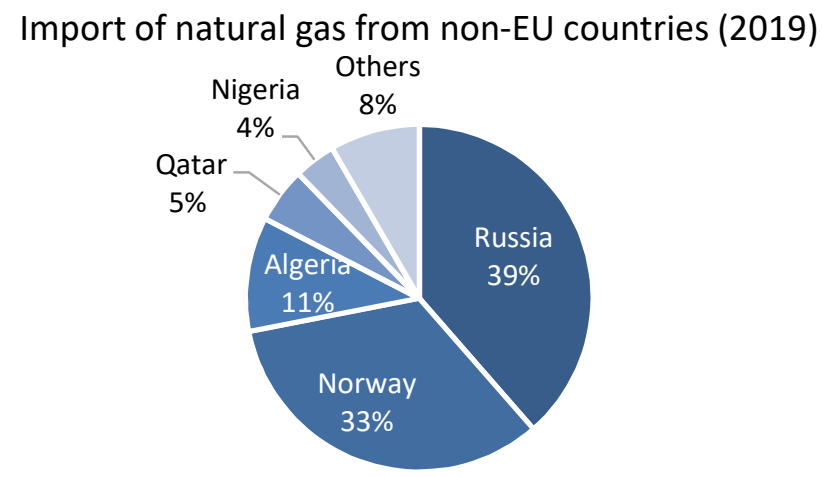

Fig.3 Import of natural gas from non - EU countries, 2019 [7]

Slovakia, Malta, Latvia, the Czech Republic, Estonia and Finland were among the countries most dependent on natural gas imports from outside of the EU in 2019. On the contrary, Denmark, the Netherlands, Cyprus and Romania were among the least dependent countries. Romania has its own natural gas reserves, so it is selfsufficient. In central European countries, natural gas supplies are currently provided mainly from Russia by the company Gazprom Export. This is why there are demands for greater diversification of gas supplies. The solution to this situation could be LNG, which would be operating through Poland. At the present, the only terminal capable of importing LNG into central European countries is the Polish Swinoujscie terminal.

LNG supplies will be the only external source of natural gas that will be able to alleviate the European market's dependence on Gazprom Export. [8]

According to World Energy Outlook, which is issued annually by the International Energy Agency (IEA), natural gas production in the EU will decrease, to fall to up to a third of today's production in 2040 (Fig.4). Gas supplies from Norway are also expected to decrease by a third by 2040, while gas supplies from Russia and 
LNG supplies will increase. The ratio between supplies from Russia and LNG will depend on gas prices on world markets and demand for natural gas in EU countries $[8,9]$.

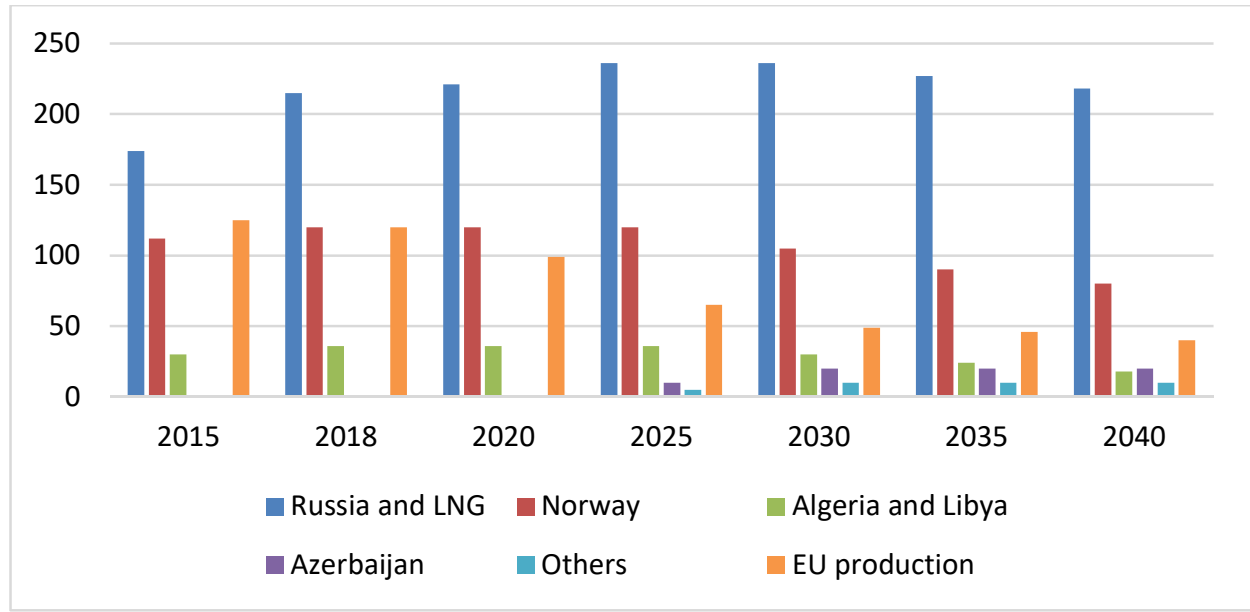

Fig.4. Outlook for expected gas supplies to the EU (in billions of $\mathrm{m}^{3}$ ), [8]

\subsection{Natural gas prices}

For natural gas prices, it is important to distinguish between prices on the commodity market and end prices for consumers. The price that consumers pay for natural gas is influenced by a number of factors, but two main components have the largest share on the price:

1. Commodity costs - the price of natural gas itself, either produced or purchased on a trading venue (so-called hub),

2. Transport and distribution costs - the cost of transporting natural gas by pipeline to local distribution networks and the cost of delivery to its consumers [10].

On the wholesale market, gas price formation is executed in two ways. In Europe, the method of indexing the price of gas has been used for a long time, which represented link of the gas price to the price of its nearest substitution product, mostly it was petrol from crude oil. The second way is the trading venue (so-called hub pricing), where the price is created [1]. Nowadays, $80-90 \%$ of the total volume sells in Europe is traded at trading venues in Great Britain (NBP - National Balancing Point)) and the Netherlands (TTF - Title Transfer Facility). Other trading venues within Europe are in Germany, Austria, Belgium, France and Italy [11]. Prices of natural gas at trading venues within individual regions of Europe are high positively correlated. 
These prices result either from long-term contracts or from spot prices. They are a function of supply and demand. In the case of demand, the increase generally leads to higher prices and the fall in demand tends to lead to lower prices. Higher prices tend to mitigate demand for natural gas [10].

\section{$\$ / \mathrm{mmBtu}$}

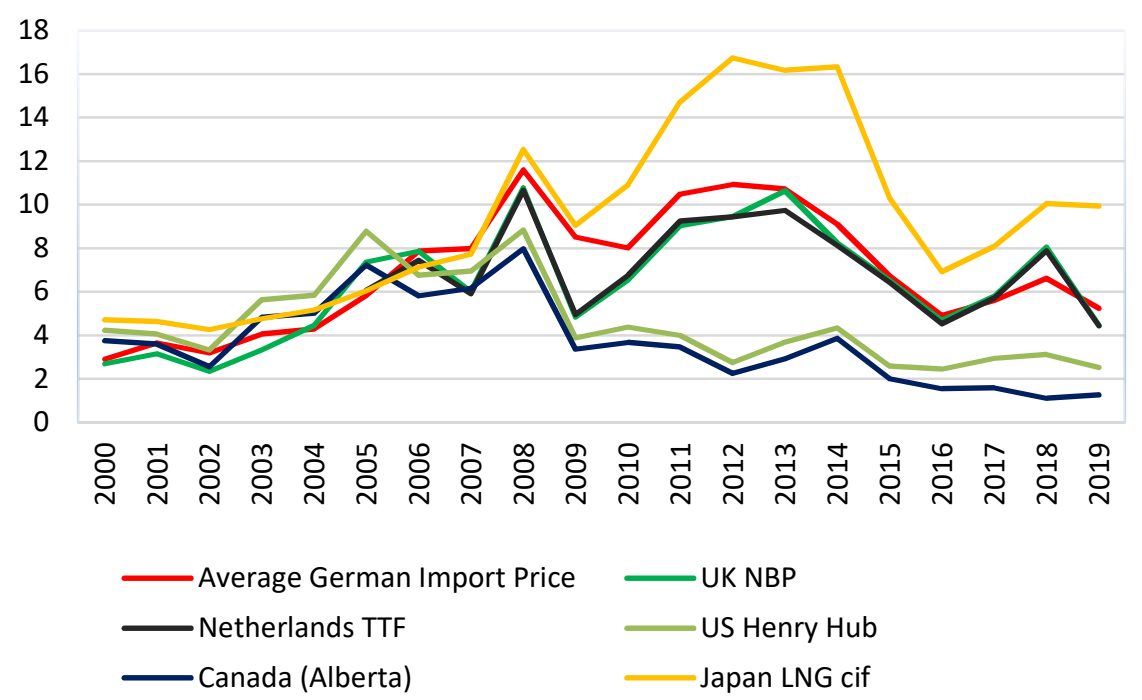

Fig.5. World prices of the natural gas $(\$ / \mathrm{mmBtu}=$ US dollars per million British thermal units), [12]

Fig.5 shows the world's natural gas prices for the last 20 years. Prices are in $\$ / \mathrm{mmBtu}$, i.e. the amount of US dollars per million British thermal units. Between 2000 and 2008, prices were roughly the same at all trading venues. Since 2009, it has been possible to see differences between the European, American and Japanese markets. European trading venues have roughly the same price set.

\subsection{Composition of consumer natural gas prices}

The price consumers pay for natural gas reflect the various elements influenced by market forces and government policy. Components of consumer prices can be divided into three groups:

1. Energy and supply - includes the commodity price of natural gas paid by the supplier and the costs which arise for the companies during the supply of gas. These include storage or production, transport and processing. Furthermore, 
the energy part forms the retail element of the price, which covers the costs associated with selling energy to final consumers [13].

2. Network - reflects infrastructure costs related to transfer and distribution, network charges and system operation costs. This component is further divided to subcomponents, transport and distribution network costs.

3. Taxes, fees, levies - include:

- value added tax;

- taxes, charges or levies related to the support of renewable energy sources;

- taxes, fees or levies related to strategic stocks, capacity payments and energy security (taxes on gas distribution, stranded costs and levies related to the financing of energy regulators or market actors);

- taxes, fees or levies related to air quality and the environment (taxes on $\mathrm{CO}_{2}$ emissions or other greenhouse gas emissions);

- all other taxes (support for district heating, local or regional fiscal charges), [13].

Energy and gas prices belong to regulated sectors. Their growth or decline in the stock market does not reflect so quickly into the final price. Regulation of natural gas prices is dealt with by CEER (Council of European Energy Regulators). Membership in CEER is open by national regulatory authority in the area of energy regulators in the EU and the European Economic Area.

An energy price in the countries of the European Union depends on different supply and demand conditions. The price is also influenced by the country's energy mix, geopolitical situation, network and environmental costs, depending on levels of excise duties [14].

\subsection{Impact of natural gas prices on countries' economy}

Energy such as oil and natural gas are an important determinant of future economic growth. Fluctuations in oil and gas prices have a significant impact on macroeconomic variables such as GDP, inflation and economic growth as a whole. The impact of these prices on macroeconomic quantities varies for countries importing or exporting oil. The price of oil and natural gas is passed through various mechanisms on economic results. Natural gas consumption is roughly half that of oil consumption, so it can be considered that the change in the price of natural gas has an overall lower effect than the change in the price of oil [15].

Economic theory predicts that a large increase in the relative price of energy will cause an increase in unit output costs, thus increasing the output price. Therefore, in the standard model of economic theory, an increase in energy prices without fiscal or monetary policy measures reduces overall output, employment and increases the price level [15]. 


\section{EVOLUTION OF NATURAL GAS PRICES IN EU COUNTRIES}

Natural gas prices vary according to the final consumer: for households prices are different from those for non-household consumers.

\subsection{Natural gas prices for households}

Natural gas prices for households increased slightly over the period 2007-2020. As can be seen on Fig.6, prices are usually higher in the second half of the year, which can be explained by seasonal effects. The figure also shows a slightly increasing trend in prices.

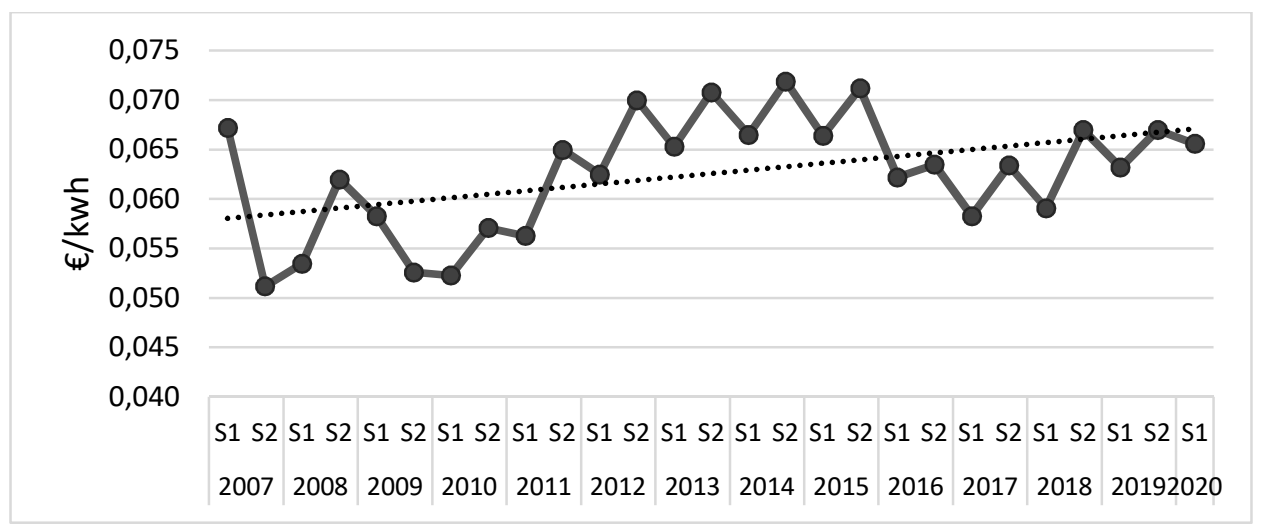

Fig.6. Gas prices for household consumers EU-28 (bi-annual data)

Note: Slowly increasing linear trend is presented by dotted line [7]

For households, prices vary significantly across EU countries (Fig.7). The lowest prices were recorded in Romania, Hungary and Croatia in 2019, while the highest in Sweden, the Netherlands and Denmark. The price of natural gas for households was in Sweden $(0,1735 € / \mathrm{kWh})$, which represents four times the price in Hungary $(0,0406 € / \mathrm{kWh})$. Prices in Slovakia $(0,0561 € / \mathrm{kWh})$ and Poland $(0,0601 € / \mathrm{kWh})$ were only about one third in comparison to Sweden.

The share of individual components in the total price of natural gas can also be seen on Fig.7. The highest component, on average $40 \%$ of the total price, consists of part of Energy and supply, and part of Network costs makes up on average 20\% of the price. 


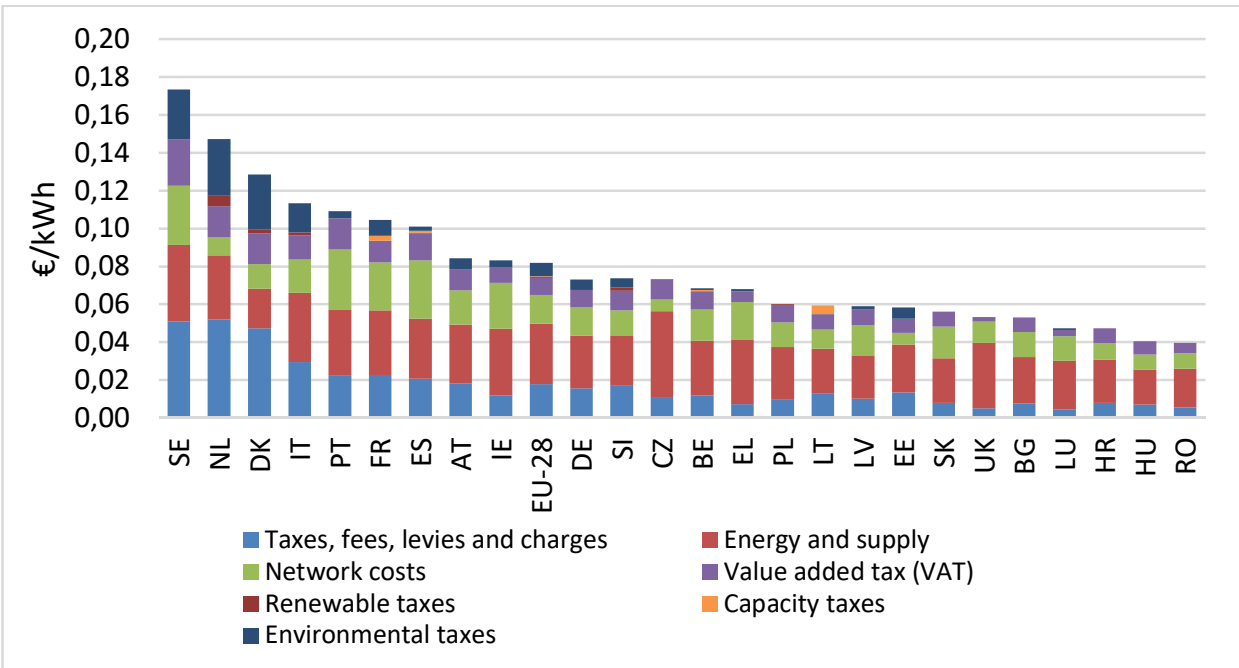

Fig.7. Gas prices components for household consumers, 2019 [7]

Natural gas prices are heavily influenced by taxes and levies such as renewable taxes, environmental taxes, value added tax (VAT) and capacity taxes. The weight of taxes and levies varies greatly between member states. The share of taxes and levies on the retail price of natural gas is shown on Fig. 8 .

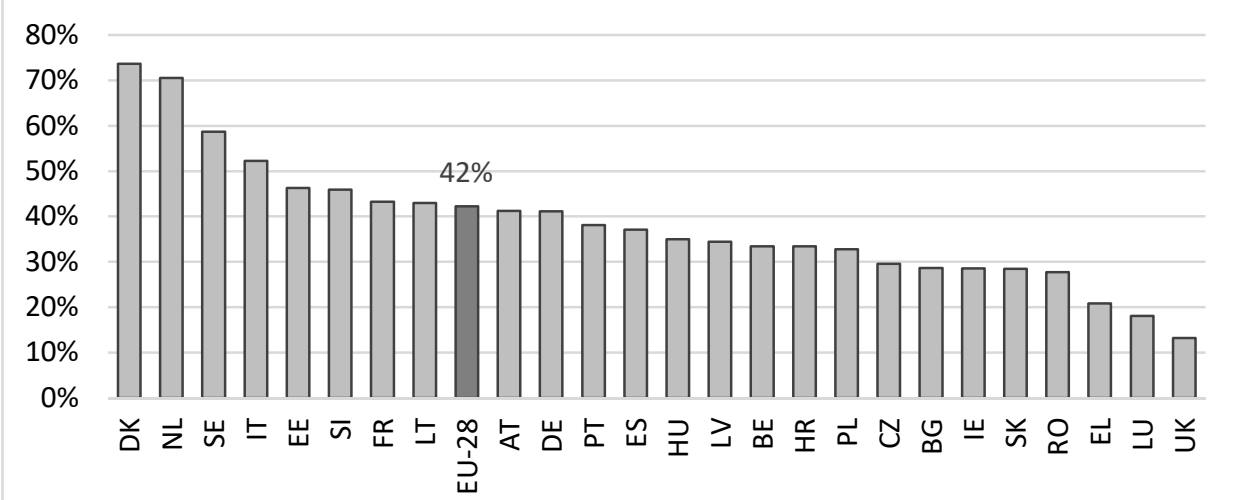

Fig.8. Share of taxes, fees, levies and charges paid by household, 2019 [7]

The highest taxes were imposed in Denmark, where they accounted for up to $74 \%$ of the price of natural gas, followed by the Netherlands (71\%) and Sweden (59\%). Conversely, the relative amount of the tax contribution was lowest in the United Kingdom (13\%) and in Luxembourg (18\%). The average in the EU-28 was 42\%. 


\subsection{Natural gas prices for non-household consumers}

The evolution of natural gas prices for non-household consumers in the EU was different from household prices in the period 2007-2020. The graph on Fig.9 shows the development of the price of natural gas for companies from group I3 (as reported by Eurostat), i.e. with a consumption of $10000 \mathrm{GJ}-100000 \mathrm{GJ}$ per year.

Since 2009, prices have shown an increase which stopped in 2013. Since then, the price has fallen every six months and in the second half of 2017 reached $0,035 € / \mathrm{kWh}$. The next two years we can see a slight increase until the first half of 2019 and again a slight decrease in 2020. Unlike natural gas prices for households, seasonal effects do not play a significant role in prices for nonhousehold consumers.

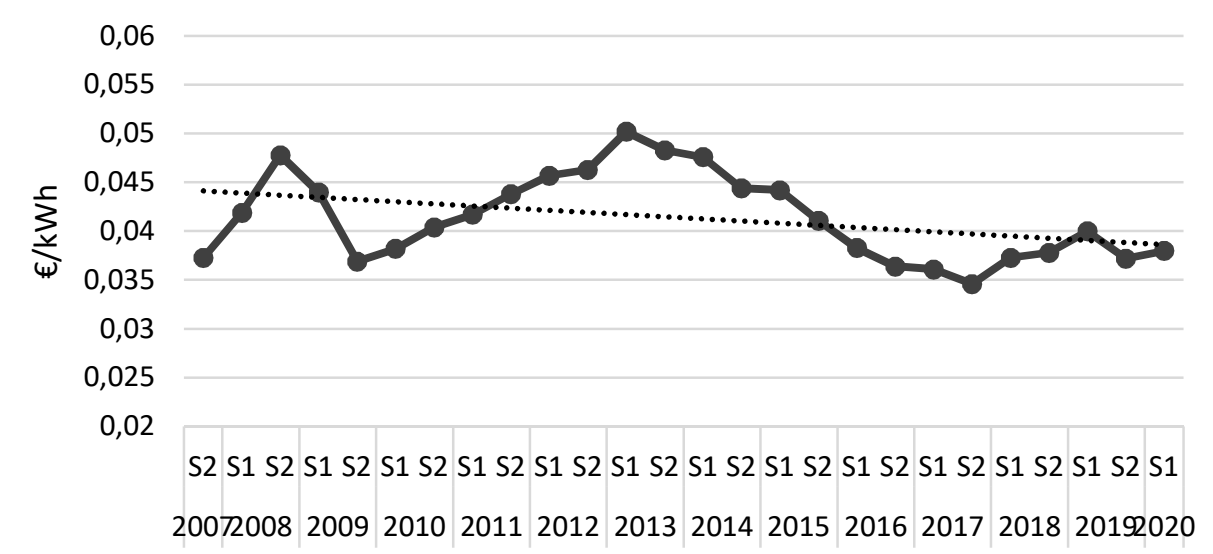

Fig.9. Gas prices for non-household consumers EU-28 - companies with consumption 10000 GJ - 100000 GJ (bi-annual data)

Note: Slowly decreasing linear trend is presented by dotted line [7]

In the case of non-household consumers, prices across the EU were more even compared to prices for households. For group of enterprises I3, companies with consumption $10000 \mathrm{GJ}-100000 \mathrm{GJ}$ per year, the lowest prices were recorded in Belgium, Luxembourg, the UK and the Czech Republic, while the highest in Sweden and Denmark (Fig.10). The price of natural gas in this group of enterprises was $0,1088 € / \mathrm{kWh}$ in Sweden, which is almost three times the price in Belgium $(0,0343 € / \mathrm{kWh})$. Prices in Slovakia $(0,0501 € / \mathrm{kWh})$ and Poland $(0,0517 € / \mathrm{kWh})$ accounted for only half of the price of natural gas in Sweden. 


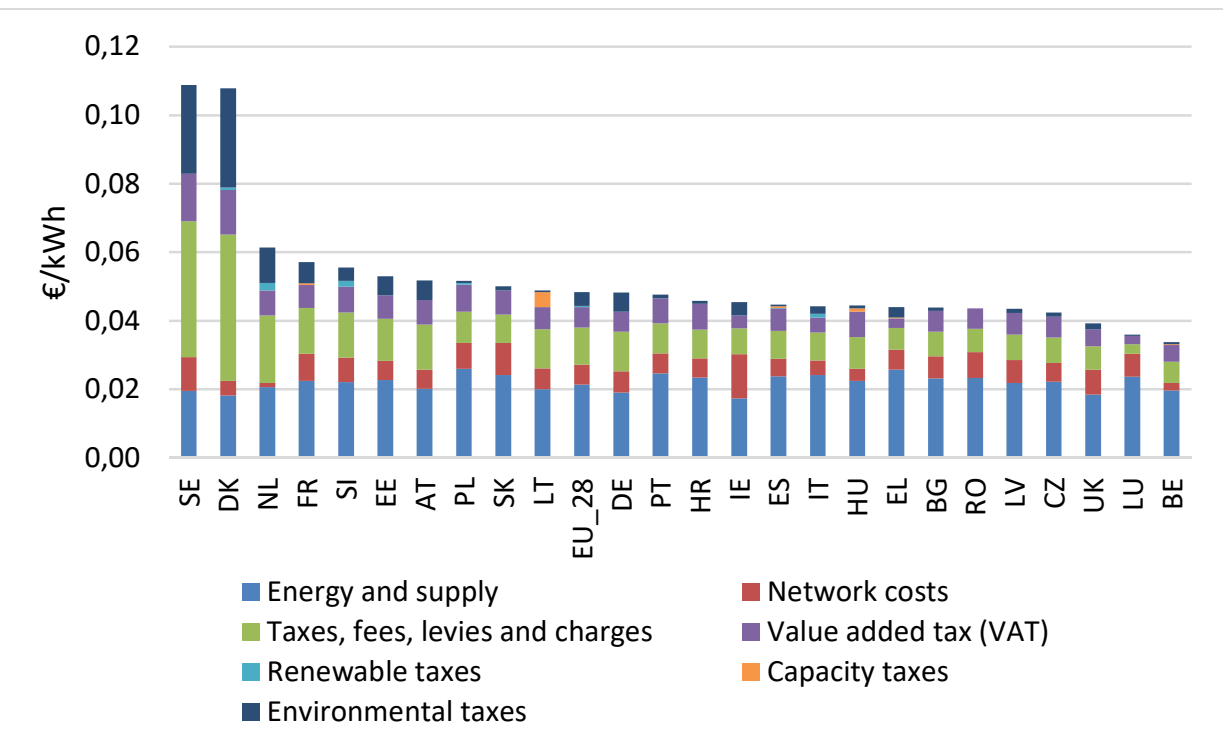

Fig.10. Gas prices components for non-household consumers (companies with consumption 10000 GJ - 100000 GJ p.a.), 2019 [7]

Fig.10 shows the natural gas price components for enterprises from the Group I3 in 2019. In western and northern European countries, environmental taxes made up significant part of the gas price. These were highest in the countries of Denmark $(27 \%)$, Sweden (24\%), and the Netherlands (17\%). In the countries of France, Austria and Germany, this tax made up for $11 \%$ of the total gas price. The energy and supply component accounted for the largest share of the price of natural gas for most countries. 


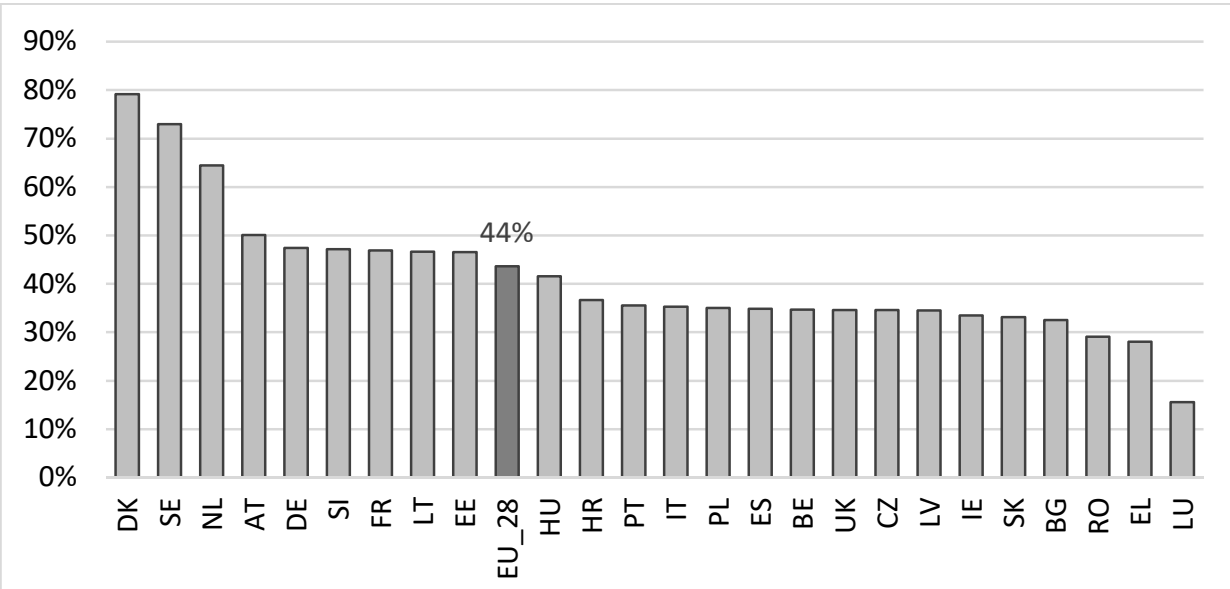

Fig.11. Share of taxes, fees, levies and charges paid by non-household consumers (companies with consumption 10000 GJ - 100000 GJ p.a.), 2019 [7]

If we take all the taxes and charges together, these were the highest in Denmark, where they represented up to $79 \%$ of the price of natural gas, followed by Sweden (73\%) and the Netherlands (64\%) (Fig.11). On the other hand, the relative amount of the tax contribution was lowest in Luxembourg (16\%), followed by Greece (28\%) and Romania (29\%). The average in the countries EU-28 was $44 \%$.

\section{ANALYSIS OF THE IMPACT OF NATURAL GAS PRICE ON INFLATION}

The aim of the authors is to build an econometric model that will examine the impact of natural gas prices together with other variables on the selected macroeconomic quantity [16]. On this basis, it can be inferred whether the development of the selected macroeconomic quantity can be predicted through a change in the price of natural gas. These contexts were followed by the example of the Slovak Republic.

The analysis first found correlations between macroeconomic quantities and commodity prices of natural gas at trading venues in Europe and then developed a possible model for inflation's dependence on the price of natural gas. 


\subsection{Correlation of natural gas prices and macroeconomic quantities}

In detecting the correlation of natural gas prices and selected macroeconomic quantities, the authors focused on natural gas prices on the Austrian market (CEGH - Central European Gas Hub), as this one is geographically closest to Slovakia [17].

The impact of the price of natural gas on the commodity market on Slovakia's inflation was analyzed. The Harmonized Index of Consumer Prices (HICP) used in the EU zone to reflect inflation was selected for analysis. It measures the time change in the prices of consumer goods and services acquired, used or paid by households in the EU zone. The term 'harmonised' refers to the fact that all countries of the European Union follow the same methodology.

In this way, it is possible to compare data for one country with data for another country. The HICP $(2015=100)$, seasonal unpurified data, were used for the model [18].

From other macroeconomic indicators, interest rate (IR) was selected to the model. The central bank's increase in interest rates also affects the increase in other interest rates and thus reduces demand for loans. This also has an impact on the economy. There will be a fall in economic growth, a fall in employment and a fall in the inflation rate. Otherwise, if the central bank cuts interest rates, the impact on the economy will be the opposite: it will cause economic growth, employment growth and, consequently, inflation growth [19].For the purposes of the model creation, interest rates were selected for household loans, which are influenced based on what interest rates are provided by the European Central Bank further to commercial banks in Slovakia.

Another important macroeconomic indicator is the unemployment rate, which also affects inflation to some extent [20].

Correlations between the variables Natural Gas Price (CEGH), Inflation (HICP), Unemployment and Interest Rate (IR) are shown in Fig.12. It can be seen that natural gas prices are negatively correlated with inflation $(r=-0.67)$ and unemployment rate $(\mathrm{r}=-0.21)$ and are positively correlated with the interest rate $(\mathrm{r}=0.63)$. 


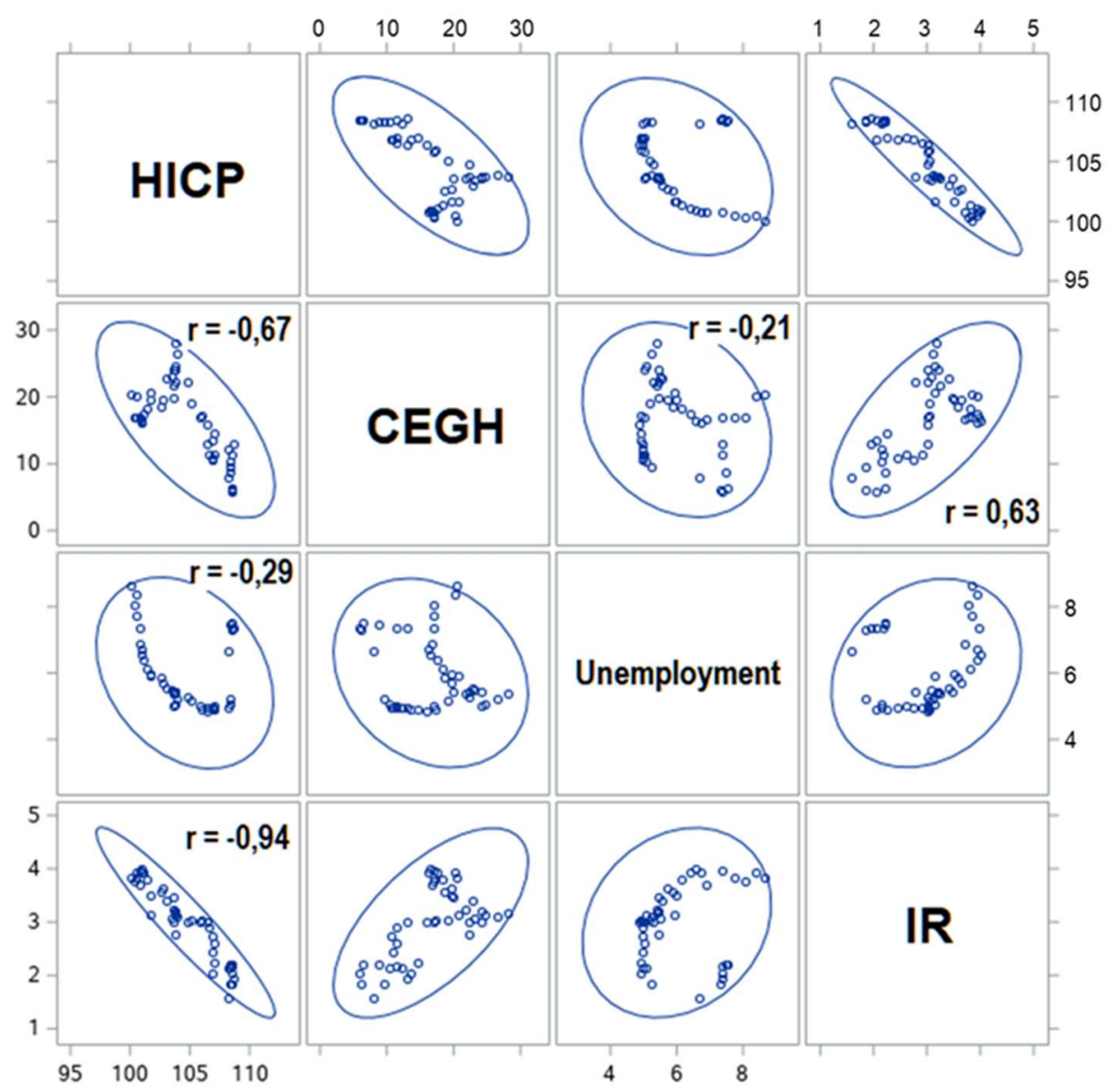

Fig.12. Variables in econometric model (HICP - Harmonized Index of Consumer Prices, CEGH - Central European Gas Hub in Austria, IR - Interest Rate) - scatter plot matrix with Pearson's correlation coefficients

Source: own processing according to National Bank of Slovakia and Eurostat

\subsection{Econometric model of inflation dependency on natural gas price, unemployment and interest rate}

The dependence of a macroeconomic quantity on several input variables can be made using a multiple linear regression model, which is also called econometric model. E.g. the authors in the article [21] use an econometric model to predict spot electricity prices. Then such a model was used to predict the possible development of electricity prices depending on several relevant variables. 
In this paper, an econometric model was used to show the development of the HICP according to the price of natural gas, unemployment and the interest rate. The data entering the model were monthly reports from January 2017 to October 2020.

The aim was to calculate the regression coefficient values in the following linear regression model:

$$
H I C P=\beta_{0}+\beta_{1} \cdot C E G H+\beta_{2} \cdot U N E M+\beta_{3} \cdot I R
$$

where:

- HICP - harmonized index of consumer prices,

- IR - interest rate,

- UNEMP - unemployment,

- CEGH - Central European Gas Hub in Austria.

The HICP variable is based on the monthly harmonised price index with base in 2015. The HICP data that have been used are seasonally unpurified. The CEGH variable is based on daily data "CEGH Day Ahead", which were averaged after months. The UNEMP variable is a collection of monthly data that explains the percentage of the number of unemployed in the total population. These are seasonally unpurified data. The IR variable represents the monthly interest rates for household loans in percentage.

The calculated value of the regressive coefficients, and thus the searched econometric model of inflation dependence on the price of natural gas, unemployment and the interest rate, is:

$$
H I C P=119,01-0,12 . C E G H-0,49 . U N E M-3,14 . I R
$$

The effects of each explanatory variable on the resulting HICP value are as follows (see equation 2):

- An increase in the price of natural gas by one unit will cause a decrease in the HICP by 0,12 .

- A $1 \%$ increase in interest rates will result in a 3,14 reduction in the HICP.

- A $1 \%$ increase in unemployment will result in a 0,49 reduction in the HICP.

The model is graphically displayed on Fig.13. Lines show the following values:

- HICP (black line) - actual HICP values for a given month

- Predicted_HICP (dotted line) - predicted values of HICP,

- lclm_HICP - lower control limit for predicted mean, 
- uclm_HICP - upper control limit for predicted mean,

- 1cl_HICP - lower control limit of 95\% confidence interval,

- ulc_HICP - upper control limit of $95 \%$ confidence interval.

What predictive capability a given model has is also shown on fig. 13. Since the parameters of the model were calculated on the basis of monthly data from January 2017 to October 2020, so in this month the graph shows the vertical. Behind this line are shown the actual HICP values of November and December 2020 and, moreover, using both the dotted line also the prediction for these two months. It can be observed that HICP predictions for November and December 2020 differ from the fact of only 0,8 units.

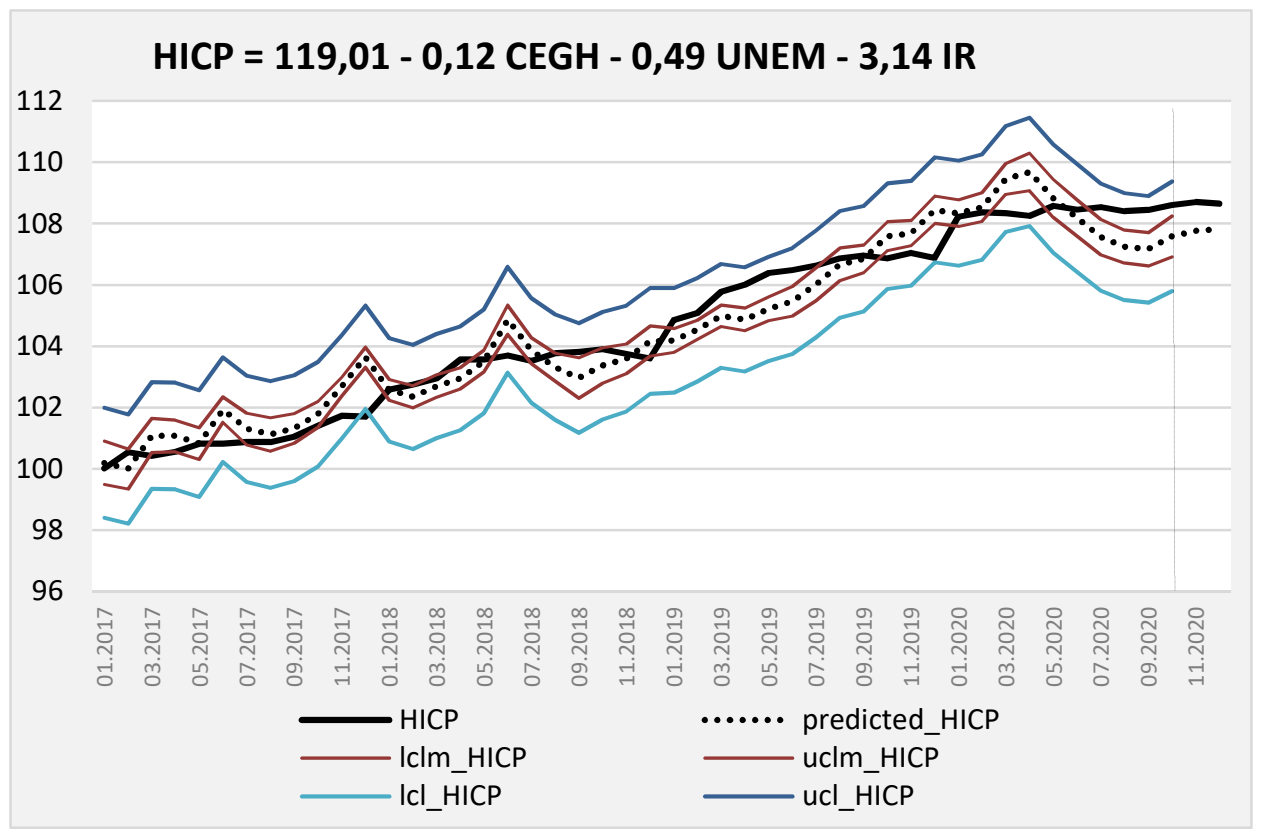

Fig.13. Econometric model

Note: $1 \mathrm{clm} \_$HICP (lower control limit for predicted mean), uclm_HICP (upper control limit for predicted mean), lcl HICP (lower control limit of $95 \%$ confidence interval), ulc_HICP (upper control limit of $95 \%$ confidence interval)

Source: own processing

The created model represents a simplification of reality, because it contains only three explanatory variables. Nevertheless, it can be concluded that natural gas prices actually have an impact on inflation. This can be followed up and used for future analyses. 


\section{CONCLUSION}

The main aim of the authors was to analyse natural gas prices from several perspectives based on theoretical knowledge, to identify correlations between natural gas prices and macroeconomic quantities and build an econometric model that examines the impact of natural gas prices on the selected macroeconomic quantity - inflation.

The authors looked at the analysis of natural gas prices from several aspects. Prices were analysed from the end consumer's point of view, in terms of the components of natural gas prices and the impact of taxes on the resulting prices. The aim was to bring the current situation with natural gas prices and price trends closer. The analyses carried out were done for the EU-28 countries. Subsequently, correlations of natural gas prices with inflation, interest rate and unemployment were quantified. Significant correlations have been confirmed between natural gas prices and inflation, unemployment and the interest rate on the basis of which the econometric model was compiled.

It is important to recall that only three variables have been included in the resulting model, so it is a simplification of the reality. Other variables, such as the exchange rate and the main interest rates, could also be used for future analyses they can refine the predictions and the model.

The econometric model presented shows good compliance with actual values. From the presented results of the simulation it is possible to notice in conclusion anomalies, could have been caused by the emergency situation related to global coronavirus epidemic.

The pressure exerted within the EU's energy policy on individual EU states is in accordance with its objectives and efforts to decarbonise Europe. The European Parliament's regulations on infrastructure of trans-European energy also contribute to this. The Regulation establishes a framework for the identification, planning and implementation of projects of common interest necessary for the implementation of strategic priority energy infrastructure corridors in the field of energy, gas and oil for the whole of Europe [22].

For this reason, the price of natural gas will in future also be based on new technologies that will contribute to reducing emissions such as replacing conventional fossil fuel and biomass heaters with condensation boilers or gas heat pumps [23] that produce lower or no $\mathrm{CO}_{2}$ emissions.

Renewable energy sources create new possibilities for reduction of energy consumption and operating costs. Biomass is an energy that is widely used by enterprises and in households. Biomass requires equipment and machines that entails input and operating costs for the firms over their lifetime. These operating costs are increasing during the lifetime of the equipment and it is necessary to look 
for the possibilities of equipment renovations from the economic point of view [24].

In the construction sector, emission reductions are mainly linked to the thermal insulation in residential buildings. In this context, a reduction in natural gas consumption is envisaged. National governments' incentives for the deployment of these technologies also contribute to this in order to meet the EU's energy policy objectives more quickly.

\section{REFERENCES}

1. Števko, M 2018. Obchodovanie so zemným plynom v Európe a vo svete. SLOVGAS 16 (2), 13-15.

2. EURACTIV: EU climate and energy policy until 2030, 2014 (https://euractiv.sk/section/energetika/linksdossier/klimaticka-aenergeticka-politika-eu-s-vyhladom-do-roku-2030-000333/ access 02.10.2021).

3. European Parliament: Fact Sheets on the European Union -| Energy policy: general principles, 2020 (https://www.europarl.europa.eu/factsheets/sk/sheet/68/energetickapolitika-vseobecne-zasady access 20.10.2020).

4. IEA: Gas - Fuels \& Technologies (https://www.iea.org/fuels-andtechnologies/gas access 29.04.2020).

5. Klepáč, J 2018. Does natural gas have a place in the future energy mix? Slovak Energy Annual, 90-93.

6. Siažik, J, Malcho, M and Lenhard, R 2017. Proposal of experimental device for the continuous accumulation of primary energy in natural gas hydrates. EPJ Web Conf. 143, 02106. https://doi.org/10.1051/epjconf/201714302106.

7. Eurostat: Data Browse- Statistics. (https://ec.europa.eu/eurostat/databrowser/view/nrg_pc_202/default/table?la ng=en access 02.10.2021).

8. Kocúrek, M 2019. Možnosti zásobavaní zemí strední Evropy zkvapalneným zemným plynem. SLOVGAS 18 (12), 12-15.

9. European Commission: EU-U.S. LNG TRADE 2019. (https://ec.europa.eu/energy/sites/ener/files/eu-us_lng_trade_folder.pdf accessed 29.04.2020).

10. EIA: Natural gas prices - U.S. Energy Information Administration. (https://www.eia.gov/energyexplained/natural-gas/prices.php access 27.04.2020).

11. Heater, P 2015. The Oxford Institute for energy studies: The evolution of European traded gas hubs. Oxford: Oxford Institute for Energy Studies. 
12. BP p.l.c.: Statistical Review of World Energy - Energy economics 2020. (https://www.bp.com/en/global/corporate/energy-economics/statisticalreview-of-world-energy.html access 02.10.2020).

13. European Commission: Energy-Energy prices and costs in Europe 2019. (https://ec.europa.eu/energy/data-analysis/energy-prices-and-costs_en accessed 29.04.2020).

14. Kliesen, KL 2006, Rising Natural Gas Prices and Real Economic Activity Federal Reserve Bank of St.Louis Review 88 (6), 511-526.

15. European Commission: Natural gas price statistics. Statistics Explained. (https://ec.europa.eu/eurostat/statisticsexplained/index.php?title=Main_Page\#Natural_gas_prices_for_household_ consumers access 20.10.2020).

16. NBS: Macroeconomic database (In Slovak: Makroekonomická databáza) (https://www.nbs.sk/sk/menova-politika/makroekonomicka-databaza access 02.10.2021).

17. Rynek Gazu: CEGH - Day ahead market. (https://rynekgazu.cire.pl/st,43,511,me,0,0,0,0,0,cegh---day-ahead-market.html access 02.10.2020).

18. European Central Bank: Measuring inflation - HICP 2021. (https://www.ecb.europa.eu/stats/macroeconomic_and_sectoral/hicp/html/in dex.en.html access 20.01.2021).

19. Petríková, D 2011. Selected problems of economic policy. (In Slovak:Vybrané problémy hospodárskej politiky). Košice: elfa Publishers.

20. Lisý, J 2007. Economy in the new economy. (In. Slovak: Ekonómia v novej ekonomike). Bratislava: Iura Edition Publishers.

21. Petrušková, K and Liptáková, E 2020. Development of electricity prices in the V4 countries and econometric model of forecasting spot electricity prices in Slovakia. Advance in Thermal Processes and Energy Transformation 3 (1), 14-24.

22. Karch, L, Škvareková, E and Kawicki, A 2018. Environmental and geological impact assessment within a project of the North - South Gas Interconnections in Central Eastern Europe. Acta Montanistica Slovaca, 23 (1), 26-38.

23. Janovcova, M, Jandačka, J and Malcho, M 2015. The impact of the weather conditions on the cooling performance of the heat pump driven by an internal natural gas combustion engine. EPJ Web of Conferences 92, 02029.

24. Teplická, K, Kováč, M, Škvareková, E and Seňová, A 2020. Economic Life Cycle of Biomass equipment and its renovation. TEM Journal: Technology, Education, Management, Informatics 9 (4), 1419 - 1425. https://ourworldindata.org/energy-mix

Editor received the manuscript: 24.02.2021 